\title{
A NEW TYPE OF HYBRID CHLOROSIS FOUND IN TETRAPLOID WHEATS ${ }^{11}$
}

\author{
KOICHIRO TSUNEWAKI AND JIN HAMADA
}

Laboratory of Genetics, Faculty of Agriculture, Kyoto University, Kyoto 606

Received May 4, 1968

A type of chlorosis caused by two complementary genes, $C h_{1}$ in $\mathrm{A}$ or $\mathrm{B}$ genome and $C h_{2}$ on chromosome $3 \mathrm{D}$ of $\mathrm{D}$ genome, is known to occur in some $\mathrm{F}_{1}$ hybrids between hexaploid wheats or between tetra- and hexaploid wheats (Tsunewaki and Kihara 1962, Nishikawa 1964, Hermsen 1966, Tsunewaki 1966). This type of chlorosis progresses with the age of plants and becomes finally lethal or semi-lethal. Distribution of the genes, $C h_{1}$ and $C h_{2}$, was extensively studied in polyploid wheats and Aegilops squarrosa, the D genome donor to common wheat (Sachs 1954, Tsunewaki and Kihara 1962, Nishikawa 1964, Tsunewaki and Hori 1967, and others). The study disclosed some phylogenetic relationships between common wheat and its ancestral species.

In the course of studying interspecific hybrids in wheat, the authors found a new type of chlorosis that occurred in reciprocal $F_{1}$ hybrids between Triticum dicoccum cultivar Hokudai and T. timopheevi var. typicum strain NIG. Since this chlorosis occurred in the $F_{1}$ hybrid with the genome constitution $A A B G$, the genic system responsible for it appeared to be different from that previously known.

In order to clarify the genetic basis of this new type of chlorosis, a conventional gene analysis has been carried out. At the same time, a preliminary investigation has been made of the distribution of the chlorosis genes in four species of tetraploid wheat. Results of those investigations are here reported.

\section{MATERIALS AND METHODS}

In 1964 three tetraploid wheats $(2 \mathrm{n}=28)$, Triticum dicoccum cultivar Hokudai (genome formula $\mathrm{AABB}$ ), $T$. durum var. reichenbachii (AABB) and $T$. timopheevi var. typicum strain NIG (AAGG), were reciprocally crossed in diallele combinations. The result indicated that some complementary genes in $T$. dicoccum and $T$. timopheevi are responsible for chlorosis, and that the $T$. durum strain does not carry them. In order to determine the number of complementary genes in the $T$. dicoccum strain, the reciprocal $F_{1}$ hybrids between $T$. dicoccum cultivar Hokudai and $T$. durum var. reichenbachii were crossed as the female parents to T. timopheevi var. typicum strain NIG (hereafter, simply called as T. timopheevi strain NIG), and their offspring were examined for the occurrence of chlorosis.

1) Contribution from the Laboratory of Genetics, Kyoto University, Kyoto, Japan, No. 337. The work has been supported by a grant from the Japan Society for the Promotion of Science as part of the Japan-U.S. Cooperative Science Program. 
In order to study the gene in the $T$. timopheevi strain, transfer of the gene to emmer wheat was attempted, because no T. timopheevi strain free from the chlorosis gene was known to us, and the $F_{1}$ hybrids between $T$. timopheevi and T. durum were highly sterile due to the difference in their second genome. For this sake, the $F_{1}$ hybrids between T. timopheevi strain NIG and T.durum var. reichenbachii were backcrossed three times to the latter as the pollen parent. In each backcross generation, plants used for further backcrosses, were test-crossed to $T$. dicoccum cultivar Hokudai, and occurrence of chlorotic plants in their offspring was examined in order to determine whether they carried the chlorosis gene. In 1967, nine $\mathrm{B}_{3}$ plants were cytologically investigated for chromosome pairing in meiosis in PMC's, and the results obtained were compared with the segregation data on chlorosis in their test-cross. Based on these results, it was decided whether the T. timopheevi gene for chlorosis is carried by a chromosome in A or $\mathrm{G}$ genome. Pedigrees of the materials used in this work are shown in Fig. 1.

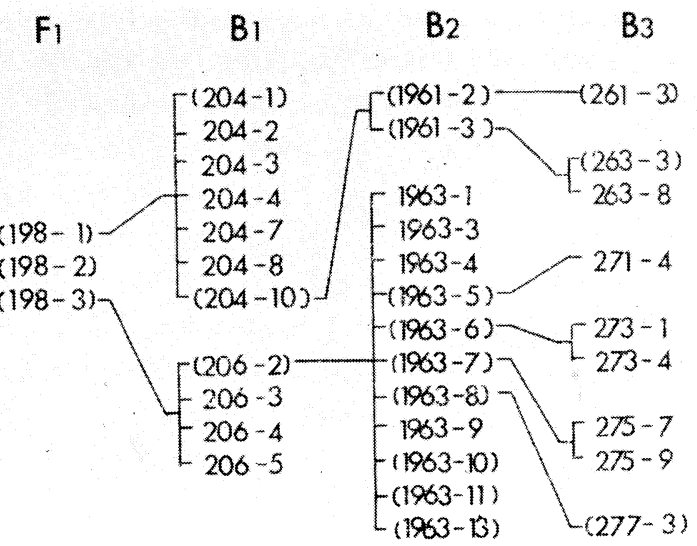

Fig. 1. Pedigree showing successful transfer of the chlorosis gene from $T$. timopheevi NIG to $T$. durum reichenbachii. (Parentheses indicate carriers of the chlorosis gene.)

In the last part of this investigation, 19 strains of emmer wheat belonging to three different species, and 12 strains of $T$. timopheevi were crossed to both $T$. dicoccum cultivar Hokudai and T. timopheevi strain NIG as testers for the chlorosis genes. Most of the emmer strains used were collected in 1959 in Mediterranean countries by Yamashita and Tanaka (1960), and were maintained by self-pollination in our laboratory. Their species and variety were identified by Dr. M. Tanaka, Kyoto University. The T. timopheevi strains were obtained in 1964 from Max-Planck Institute, all of which were originally collected in Gruzia, Caucasus. The $F_{1}$ hybrids between these materials and the two testers were grown in the field, and occurrence of chlorosis was observed, and their genotype for chlorosis was determined. 


\section{RESULTS}

\section{(1) General observation}

Result of the diallele crosses between $T$. dicoccum cultivar Hokudai, T. durum var. reichenbachii and $T$. timopheevi strain NIG is shown in Table 1 ; in no caso the reciprocal $\mathrm{F}_{1}$ 's showed a difference in their phenotype, indicating that this type of chlorosis is not caused by cytoplasmic factors.

Table 1. Result of the diallele crosses between three species of tetraploid wheat

\begin{tabular}{cc}
\hline $\mathrm{F}_{1}$ hybrids $($ + $\times \hat{\delta})$ & Phenotype \\
\hline$T$. dicoccum Hokudai $\times T$. durum reichenbachii & normal \\
reciprocal & " \\
$T$. dicoccum Hokudai $\times T$. timopheevi $\mathrm{NIG}$ & chlorotic \\
reciprocal & " \\
$T$. durum reichenbachii $\times T$. timopheevi $\mathrm{NIG}$ & normal \\
reciprocal & " \\
\hline
\end{tabular}

Chlorosis appeared in early tillering stage, while in younger stage the plants did not differ from normal seedlings. When seeds were sown in October, chlorosis began to

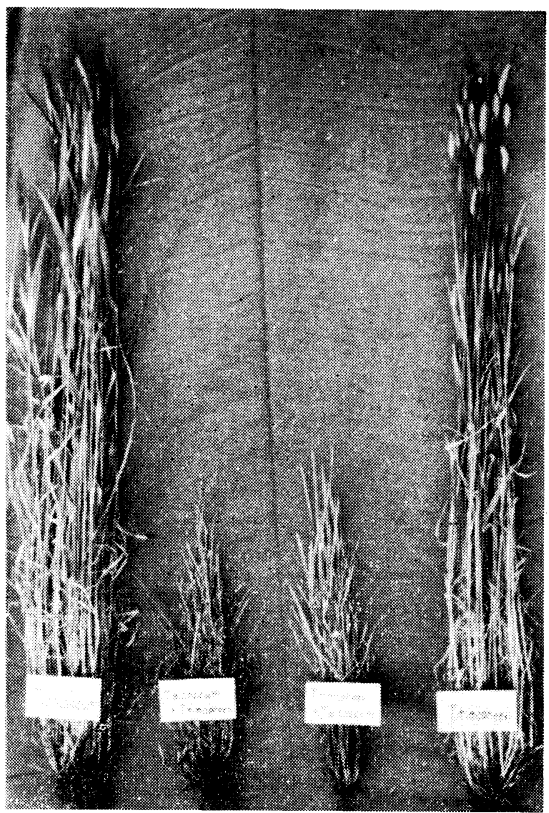

Fig. 2. Chlorosis appeared in reciprocal $F_{1}$ hybrids between $T$. dicoccum Hokudai and T. timopheevi NIG. From left to right: T. dicoccum, T. dicoccum $\times$ T. timopheevi $\mathrm{F}_{1}, T$. timopheevi $\times T$. dicoccum $\mathrm{F}_{1}$ and $T$. timopheevi.

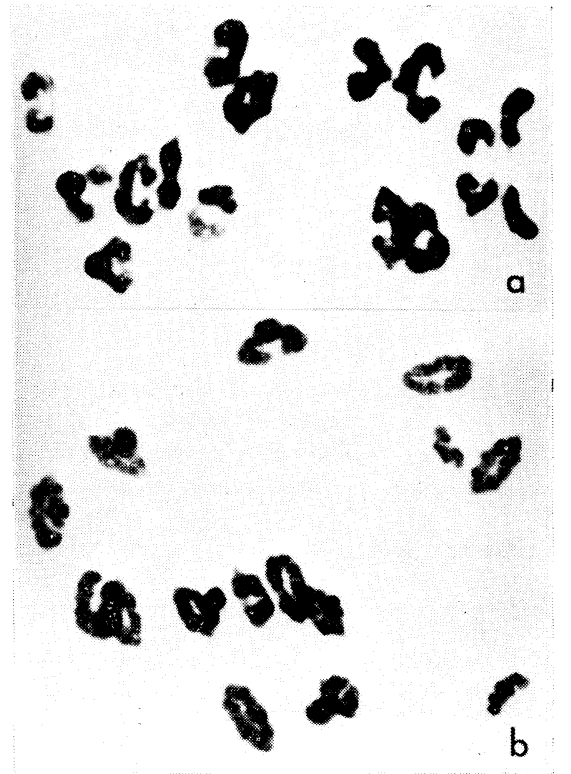

Fig. 3. Chromosome pairing in MI of PMC's in $\mathrm{B}_{3}$ plants ( $T$. timopheevi $\mathrm{NIG} \times T$. durum reichenbachii ${ }^{4}$ ).

a. $14_{\text {II }}$ found in plant, 275-9.

b. $13_{\text {II }}+2_{\text {I }}$ found in plant, 277-3. 
appear in December; though tillering was almost normal, chlorosis progressed gradually from older leaves to younger ones, and from leaf tip to base. Chlorotic plants at this stage appeared pale-green rather than yellow-green, the common appearance of the previously known type. In April all leaves showed severe chlorosis and stunted growth, and as a consequence no plants headed. Appearance in the middle of May of the reciprocal $F_{1}$ hybrids between T. dicoccum cultivar Hokudai and T.timopheevi strain NIG is shown in Fig. 2 with their parents for comparison.

(2) Analysis of the genes for chlorosis

Results of the cross, ( $T$. dicoccum cultivar Hokudai $\times T$. durum var. reichenbachii) $\mathrm{F}_{1} \times T$. timopheevi strain NIG, are summarized in Table $2 . \quad$ In all five test-crossed populations, segregation into normal and chlorotic plants fitted well to $1: 1$ ratio, indicating that $T$. dicoccum cultivar Hokudai carries a single chlorosis gene which interacts with the gene of $T$. timopheevi.

As described in "Materials and Methods", transfer of the T. timopheevi gene to emmer background has been attempted by backcross method. In the $B_{1}$ generation of

Table 2. Segregation of normal and chlorotic plants in the cross, ( $T$. dicoccum Hokudai $\times T$. durum reichenbachii) $\mathrm{F}_{1} \times T$. timopheevi $\mathrm{NIG}$

\begin{tabular}{|c|c|c|c|c|c|}
\hline \multirow{2}{*}{\multicolumn{2}{|c|}{$F_{1}$ parent (cross combination) }} & \multicolumn{3}{|c|}{ No. of plants } & \multirow{2}{*}{$\begin{array}{c}\chi^{2} \text { value } \\
(1: 1)\end{array}$} \\
\hline & & Total & Normal & Chlorotic & \\
\hline \multicolumn{2}{|c|}{ 266- $4(T$. dicoccum $\times T$. durum $)$} & 87 & 43 & 44 & 0.01 \\
\hline$\prime \prime-5($ & ) & 106 & 58 & 48 & 0.94 \\
\hline \multicolumn{2}{|c|}{ 267-10 (T. durum $\times T$. dicoccum $)$} & 33 & 15 & 18 & 0.27 \\
\hline " -18 & ) & 80 & 46 & 34 & 1.80 \\
\hline \multirow[t]{2}{*}{$/ 19($} & ) & 19 & 8 & 11 & 0.47 \\
\hline & & 325 & 170 & 155 & 0.69 \\
\hline
\end{tabular}

Table 3. Results of the test-cross to $T$. dicoccum Hokudai and the backcross to $T$. durum reichenbachii of the $\mathrm{B}_{1}$ plants, $(T$. durum reichenbachii $\times T$. timopheevi NIG) $\mathrm{F}_{1} \times T$. durum reichenbachii

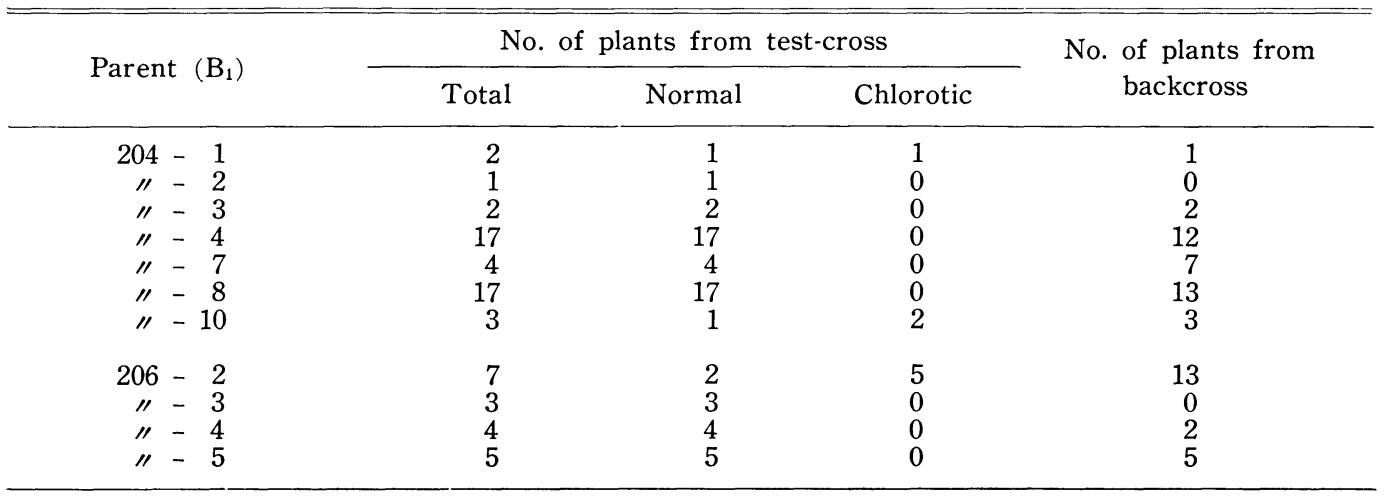


the cross, (T. durum var. reichenbachii $\times T$. timopheevi strain NIG) $F_{1} \times T$. durum var. reichenbachii, 11 plants were selected, and crossed to both $T$. dicoccum cultivar Hokudai and T. durum var. reichenbachii. Results of these crosses are summarized in Table 3. In three progenies of the test-cross, some chlorotic plants were obtained among normals. It is evident that the three $B_{1}$ plants, 204-1, 204-10 and 206-2, received the chlorosis gene from T. timopheevi strain NIG.

Backcrossed offspring of these $B_{1}$ 's were grown, and $13 B_{2}$ plants selected from them were again crossed to both $T$. dicoccum cultivar Hokudai and $T$. durum var. reichenbachii, the results being summarized in Table 4 . Test-crossed offspring of nine $\mathrm{B}_{3}$ plants segregated some chlorotic plants, suggesting that they were the carriers of the timopheevi gene.

Backcrossed offspring of these $B_{2}$ 's were grown, and nine selected $B_{3}$ plants were

Table 4. Results of the test-cross to $T$. dicoccum Hokudai and the backcross to $T$. durum reichenbachii of the $\mathrm{B}_{2}$ plants, $(T$. durum reichenbachii $\times T$. timopheevi NIG) $F_{1} \times T$. durum reichenbachii ${ }^{2}$

\begin{tabular}{|c|c|c|c|c|}
\hline \multirow{2}{*}{ Parent $\left(B_{2}\right)$} & \multicolumn{3}{|c|}{ No. of plants from test-cross } & \multirow{2}{*}{$\begin{array}{l}\text { No. of plants from } \\
\text { backcross }\end{array}$} \\
\hline & Total & Normal & Chlorotic & \\
\hline $1961-2$ & 8 & 3 & 5 & 8 \\
\hline$\prime \prime-3$ & 14 & 9 & 5 & 9 \\
\hline $1963-1$ & 22 & 22 & 0 & 17 \\
\hline$\prime \prime-3$ & 21 & 21 & 0 & 21 \\
\hline "I -4 & 17 & 17 & 0 & 17 \\
\hline$\prime \prime-5$ & 8 & 4 & 4 & 7 \\
\hline$" \prime-6$ & 16 & 8 & 8 & 12 \\
\hline$" 11-7$ & 22 & 10 & 12 & 18 \\
\hline$\prime \prime-8$ & 12 & 3 & 9 & 13 \\
\hline$\prime \prime-9$ & 1 & 1 & 0 & 14 \\
\hline "I -10 & 17 & 11 & 6 & 18 \\
\hline "I -11 & 15 & 6 & 9 & 12 \\
\hline " & 15 & 5 & 10 & 11 \\
\hline
\end{tabular}

Table 5. Chromosome pairing in nine $\mathrm{B}_{3}$ plants and occurrence of chlorosis in their test-crossed offspring to $T$. dicoccum Hokudai

\begin{tabular}{|c|c|c|c|c|c|}
\hline \multirow{2}{*}{$\begin{array}{l}\text { Plant } \\
\text { no. }\left(B_{3}\right)\end{array}$} & \multirow{2}{*}{$\begin{array}{l}\text { No. of PMC's } \\
\text { observed }\end{array}$} & \multirow{2}{*}{$\begin{array}{l}\text { Chromosome } \\
\text { association }\end{array}$} & \multicolumn{2}{|c|}{ No. of plants from test-cross } & \multirow{2}{*}{$\begin{array}{l}\chi^{2} \text {-value } \\
(1: 1)\end{array}$} \\
\hline & & & Normal & Chlorotic & \\
\hline $\begin{array}{l}261-3 \\
263-3 \\
277-3 \\
\text { Total }\end{array}$ & $\begin{array}{r}50 \\
50 \\
50 \\
150\end{array}$ & $\begin{array}{r}1 \text { II }+12_{\text {II }}+1_{\text {I }} \\
133_{\text {I }}+2_{\text {I }} \\
13_{\text {II }}+2 \text { I }\end{array}$ & $\begin{array}{l}1 \\
1 \\
1 \\
3\end{array}$ & $\begin{array}{l}0 \\
2 \\
1 \\
3\end{array}$ & $\begin{array}{l}\overline{-} \\
\overline{0.0}\end{array}$ \\
\hline $\begin{array}{l}263-8 \\
271-4 \\
273-1 \\
273-4 \\
275-7 \\
275-9 \\
\text { Total }\end{array}$ & $\begin{array}{r}50 \\
50 \\
50 \\
50 \\
17 \\
50 \\
267\end{array}$ & $\begin{array}{l}14_{\text {II }} \\
14_{\text {II }} \\
14_{\text {II }} \\
14_{\text {II }} \\
14_{\text {II }} \\
14_{\text {II }}\end{array}$ & $\begin{array}{r}5 \\
2 \\
1 \\
2 \\
2 \\
1 \\
13\end{array}$ & $\begin{array}{l}0 \\
0 \\
0 \\
0 \\
0 \\
0 \\
0\end{array}$ & $\begin{array}{l}- \\
\overline{-} \\
\overline{-} \\
\overline{1} \\
13.0^{* *}\end{array}$ \\
\hline
\end{tabular}

** Significant at the $1 \%$ level 
further test- and backcrossed. At the same time, chromosome pairing in meiotic metaphase was observed with the results shown in Table 5 . Three $B_{3}$ plants, 261-3, 263-3 and $277-3$, showed a chromosome association, $1_{\mathrm{III}}+12_{\mathrm{II}}+1_{\mathrm{I}}$ or $13_{\mathrm{II}}+2_{\mathrm{I}}$ (Fig. $3 \mathrm{~b}$ ), and two of them segregated chlorotic plants in test-crossed offspring. Plant 261-3 did not segregate any chlorotic plant, probably due to a very small size of the test-crossed offspring. One of the two univalents found in 263-3 and 277-3 must be a timopheevi chromosome, that can not form a bivalent with any chromosome of $T$. durum var. reichenbachii. Consequently, this chromosome should have belonged to the $\mathrm{G}$ genome. Formation of a trivalent in 261-3 suggests that this plant carried reciprocal translocations between an emmer chromosome of $\mathrm{A}$ or $\mathrm{B}$ genome and the $\mathrm{G}$ genome chromosome from T. timopheevi, because if the translocations were taking place between any two chromosomes of $\mathrm{A}$ and/or $\mathrm{B}$ genome, a quadrivalent instead of a trivalent plus a univalent should have been formed. Six other $B_{3}$ plants had all 14 bivalents (Fig. $3 \mathrm{a}$ ), and none segregated chlorotic plants. Apparently, they did not receive any chromosome of $\mathrm{G}$ genome from T. timopheevi. All those informations point to the fact that the complementary gene present in T. timopheevi strain NIG is located on a single G-genome chromosome, which has been transferred, at least, to two $B_{3}$ plants with 28 chromosomes.

Segregation data in all test-crossed offspring, which segregated normal and chlorotic plants, are summarized in Table 6 ; their ratios in the $B_{1}, B_{2}$ and $B_{3}$ generations fitted all to the $1: 1$ ratio. Since all nine $B_{3}$ plants, which were derived from $B_{2}$ plants carrying one G-genome chromosome, had 28 chromosomes somatically, a great majority of fertilized female gametes from $13_{\text {II }}+2_{\text {I }}$ plants seemed to have 14 chromosomes, i.e. either the full complement of emmer chromosomes or 13 emmer chromosomes plus one timopheevi chromosome. In other words, gametes having only 13 emmer chromosomes or

Table 6. Number of normal and chlorotic plants obtained in segregating lines of the test-cross in three backcross generations

\begin{tabular}{|c|c|c|c|c|c|}
\hline \multirow{2}{*}{ Generation } & \multirow{2}{*}{ Parent } & \multicolumn{3}{|c|}{ No. of plants } & \multirow{2}{*}{$\begin{array}{c}\chi^{2} \cdot \text { value } \\
(1: 1)\end{array}$} \\
\hline & & Total & Normal & Chlorotic & \\
\hline $\begin{array}{l}\mathrm{B}_{1} \\
\prime \prime \\
\prime \prime \\
\prime \prime\end{array}$ & $\begin{array}{r}204-1 \\
\prime \prime-10 \\
206-2 \\
\text { total }\end{array}$ & $\begin{array}{r}2 \\
3 \\
7 \\
12\end{array}$ & $\begin{array}{l}1 \\
1 \\
2 \\
4\end{array}$ & $\begin{array}{l}1 \\
2 \\
5 \\
8\end{array}$ & $\frac{-}{\overline{-}}$ \\
\hline $\begin{array}{l}\mathrm{B}_{2} \\
\prime \prime \\
\prime \prime \\
\prime \prime \\
\prime \prime \\
\prime \prime \\
\prime \prime \\
\prime \prime \\
\prime \prime\end{array}$ & $\begin{array}{c}1961-2 \\
\prime \prime-3 \\
1963-5 \\
\prime \prime-6 \\
\prime \prime-7 \\
\prime \prime-8 \\
\prime \prime-10 \\
" \text { " }-11 \\
\text { total }\end{array}$ & $\begin{array}{r}8 \\
14 \\
8 \\
16 \\
22 \\
12 \\
17 \\
15 \\
15 \\
127\end{array}$ & $\begin{array}{r}3 \\
9 \\
4 \\
8 \\
10 \\
3 \\
11 \\
6 \\
5 \\
59\end{array}$ & $\begin{array}{r}5 \\
5 \\
4 \\
8 \\
12 \\
9 \\
6 \\
9 \\
10 \\
68\end{array}$ & $\begin{array}{l}\bar{z} \\
\bar{z} \\
\bar{z} \\
\bar{z} \\
\overline{-} \\
0.64\end{array}$ \\
\hline $\begin{array}{l}\mathrm{B}_{3} \\
\prime \prime \\
\prime \prime\end{array}$ & $\begin{array}{c}263-3 \\
277-3 \\
\text { total }\end{array}$ & $\begin{array}{l}3 \\
2 \\
5\end{array}$ & $\begin{array}{l}1 \\
1 \\
2\end{array}$ & $\begin{array}{l}2 \\
1 \\
3\end{array}$ & $\overline{-}$ \\
\hline \multicolumn{2}{|c|}{ Grandtotal } & 144 & 65 & 79 & 1.36 \\
\hline
\end{tabular}


Table 7. Occurrence of chlorosis in $F_{1}$ hybrids between 34 strains of tetraploid wheat and the two testers, T. dicoccum Hokudai and T. timopheevi NIG

\begin{tabular}{|c|c|c|c|c|c|}
\hline \multirow{2}{*}{ Strain } & \multirow{2}{*}{ Species } & \multirow{2}{*}{ Variety } & \multicolumn{2}{|c|}{ Testers } & \multirow{2}{*}{$\begin{array}{l}\text { Designated } \\
\text { genotype }^{1)}\end{array}$} \\
\hline & & & dicoccum & timopheevi & \\
\hline 3591 & $T$. dicoccoides & pseudo-rufovillosum & + & + & $c h l_{1}$ \\
\hline 4343 & T. dicoccum & brunneum & + & + & $" 1$ \\
\hline 4346 & "I & farrum & + & + & "I \\
\hline 1684 & "I & (Hokudai) & + & c & $C h l_{1}$ \\
\hline 4060 & T. durum & aegyptianum & + & + & $c h l_{1}$ \\
\hline 4108 & " & affine & + & + & $" \prime$ \\
\hline 4067 & $\prime \prime$ & africanum & + & + & $" \prime$ \\
\hline 4351 & "I & albo-provinciale & + & + & "I \\
\hline 4353 & "I & apilicum & + & + & $" \prime$ \\
\hline 4115 & $" \prime$ & hordeiforme & + & + & "I \\
\hline 4360 & "I & italicum & + & + & "I \\
\hline 4361 & $\prime \prime$ & leucurum & + & + & $" 1$ \\
\hline 4053 & "I & muriciense & + & + & "I \\
\hline 4057 & "I & II & + & + & "I \\
\hline 4071 & "I & $" \prime$ & + & + & $" \prime$ \\
\hline 4098 & "I & $" \prime$ & + & + & "I \\
\hline 4116 & "I & "I & + & + & "I \\
\hline 4123 & $" \prime$ & $" \prime$ & + & + & $\prime \prime$ \\
\hline 4126 & $" \prime$ & "I & + & + & $" 1$ \\
\hline 4055 & $" 1$ & reichenbachii & + & + & "I \\
\hline 1685 & "I & "I & + & + & " \\
\hline 3592 & $T$. timopheevi & viticulosum & c & + & $C h l_{2}$ \\
\hline 3593 & " & typicum & c & + & "I \\
\hline 3594 & $" 1$ & II & c & + & "I \\
\hline 3595 & "I & "I & c & + & "I \\
\hline 3596 & "I & "I & c & + & "I \\
\hline 3597 & $" 1$ & "I & c & + & $\prime \prime$ \\
\hline 3598 & "I & "I & c & + & "I \\
\hline 3599 & "I & "I & c & + & "I \\
\hline 3600 & "I & $\prime \prime$ & c & + & "I \\
\hline 3601 & "I & "I & c & + & "I \\
\hline 3602 & "I & "I & c & + & "I \\
\hline 3603 & "I & "I & c & + & "I \\
\hline 1703 & "I & "I & c & + & "I \\
\hline
\end{tabular}

$+:$ normal $F_{1}, c$ : chlorotic $F_{1}$

1) All timopheevi strains will possess $c h l_{1}$, if $C h l_{1}$ locus is in A genome.

a full emmer complement plus a timopheevi chromosome (15 chromosomes in total), which are produced by 2:0 segregation of the two univalents, seem to be rarely functional in fertilization. Based on this consideration, the $1: 1$ segregation ratio obtained from the test-crosses in three successive backcross generations is reasonably understood.

\section{(3) Distribution of the chlorosis genes}

Results of the gene analysis described above demonstrated that the single gene of $T$. dicoccum cultivar Hokudai and the gene on a single chromosome of the Genome in T. timopheevi strain NIG are complementary to each other in causing chlorosis. A preliminary survey of these genes in emmer and timopheevi wheats was carried out; the results are summarized in Table 7. No emmer strains, except T. dicoccum cultivar Hokudai, showed chlorosis in their $\mathrm{F}_{1}$ hybrids with either tester. On the contrary, all timopheevi strains gave rise to chlorotic $\mathrm{F}_{1}$ hybrids, when crossed to $T$. dicoccum cultivar Hokudai. The result clearly indicates that T. timopheevi is distinctly different 
from the emmer species by having one of the complementary genes for the new type of chlorosis.

\section{DISCUSSION}

The kind of chlorosis studied in the present investigation occurred in $\mathrm{F}_{1}$ hybrids between $T$. dicoccum cultivar Hokudai (genome formula $\mathrm{AABB}$ ) and T. timopheevi var. typicum strain NIG (AAGG). The former carried one of the complementary genes for this chlorosis, while a single chromosome of $T$. timopheevi, that belonged to $\mathrm{G}$ genome, carried the other complementary gene.

Chlorosis, that has been previously known to us, is controlled by two complementary genes, $C h_{1}$ in $\mathrm{A}$ or $\mathrm{B}$ genome and $C h_{2}$ on chromosome $3 \mathrm{D}$ of $\mathrm{D}$ genome. Chlorosis under the present investigation is controlled similarly by two complementary genes, but is clearly different from the previously known type, because one of the complementary genes for the present chlorosis is located in G but not in D genome, and the other complementary gene located in A or B genome of $T$. dicoccum cultivar Hokudai is different from $C h_{1}$, because $F_{1}$ hybrids between $T$. dicoccum cultivar Hokudai and T. aestivum cultivar Chinese Spring $\left(\mathrm{Ch}_{2}\right.$-carrier) are completely normal. There is, also, some difference in expression of chlorosis between the two types.

The new type of chlorosis will be called as "chlorosis type 2", the name "chlorosis type 1" being given to the previously known type. The complementary genes for chlorosis type 2 will be symbolized by " $\mathrm{Chl}$ ", different from " $\mathrm{Ch}$ " for the genes of chlorosis type 1 by a third letter, both meaning chlorosis. The gene in T. dicoccum cultivar Hokudai will be designated as $C h l_{1}$ and that in $T$. timopheevi as $C h l_{2}$.

The $C h l_{1}$ locus is located on a chromosome of $\mathrm{A}$ or $\mathrm{B}$ genome. If it were in $\mathrm{A}$ genome, T. timopheevi would possess this locus, if not it can be present only in emmer wheat. The $\mathrm{Chl}_{2}$ locus is on a G-genome chromosome, therefore emmer wheat can not have it. From these considerations, the genotype for chlorosis type 2 can be designated for all emmer and timopheevi strains, which were investigated in the present study

Table 8. Frequency of three possible genotypes for chlorosis in four tetraploid wheat species

\begin{tabular}{lcccc}
\hline \multirow{2}{*}{ Species } & \multicolumn{4}{c}{ No. of strains } \\
\cline { 2 - 5 } & $c h l_{1}$ & $C h l_{1}$ & $C h l_{2}$ & Total \\
\hline$T$. dicoccoides & 1 & 0 & - & 1 \\
$T$. dicoccum & 2 & 1 & - & 3 \\
$T$. durum & 17 & 0 & - & 17 \\
$\quad$ Total & 20 & 1 & - & 21 \\
$T$. timopheevi ${ }^{1}$ & - & - & 13 & 13 \\
\hline
\end{tabular}

1) T. timopheevi will possess $c h l_{1}$ in addition to $C h l_{2}$, if $C h l_{1}$ locus is located in A genome. 
(Table 7). The results are summarized in Table 8 . Out of 20 emmer wheats, only T. dicoccum cultivar Hokudai possessed $C h l_{1}$ gene, while all the others carried its recessive allele. All strains of $T$. timopheevi had $C h l_{2}$ gene, that was, of course, never found in emmer wheat

T. timopheevi is distinctly different from emmer wheat as to some morphological characteristics as well as genome constitution and cytoplasm (Lilienfeld and Kihara 1934, Kihara and Tsunewaki 1967). The present result indicates, in addition, that T. timopheevi is genically different from emmer wheat. A future investigation on distribution of this gene in T. araraticum (AAGG) and T. zhukovskyi (AAAAGG) might throw a further light on the evolution of the timopheevi complex in polyploid wheat.

\section{SUMMARY}

1. A new type of progressive chlorosis was found to occur in reciprocal $F_{1}$ hybrids between Triticum dicoccum cultivar Hokudai $(2 \mathrm{n}=28$, genome formula $\mathrm{AABB})$ and $T$. timopheevi var. typicum strain NIG $(2 \mathrm{n}=28$, AAGG); it was named "chlorosis type 2".

2. Two complementary genes cause chlorosis type 2 ; they were designated by $C h l_{1}$ and $C h l_{2}$. T. dicoccum cultivar Hokudai carries $C h l_{1}$ on a chromosome in A or B genome, while $T$. timopheevi strain NIG possesses $C h l_{2}$ on a chromosome in Genome.

3. Other 19 emmer strains belonging to three different species carried only $c h l_{1}$ gene, while all 13 strains of $T$. timopheevi possessed $C h l_{2}$ gene; the species, T. timopheevi, is distinctly different from emmer wheat as to its population structure for the chlorosis genes.

\section{ACKNOWLEDGMENT}

The authors wish to express their sincere appreciation to Dr. F. A. Lilienfeld for her helpful criticism and suggestions to this manuscript.

\section{LITERATURE CITED}

Hermsen, J.G. Th., 1966 Hybrid necrosis and red hybrid chlorosis in wheat. Proc. II Int. Wheat Genet. Symp. (Hereditas Suppl. Vol. 2): 439-452.

Kihara, H., and K. Tsunewaki, 1967 Genetic principles applied to the breeding of crop plants. Heritage from Mendel (Univ. Wisc. Press): 403-418.

Lilienfeld, F., and H. Kihara, 1934 Genomanalyse bei Triticum und Aegilops. V. Triticum Timopheevi Zhuk. Cytologia 6: 87-122.

Nishikawa, K., 1964 Cytogenetical study on the artificial synthesis and origin of common wheat. (in Japanese with English résumé). Res. Bull. Fac. Agr. Gifu Univ. 20: 1-55.

Sachs, L., 1954 Reproductive isolation in Triticum. Proc. IX Int. Congr. Genet. 2: 1145-1146.

Tsunewaki, K., 1966 Gene analysis on chlorosis of the hybrid, Triticum aestivm var. Chinese Spring $\times T$. macha var. subletschchumicum, and its bearing on the genetic basis of necrosis and chlorosis. Japan. J. Genetics. 41: 413-426. 
Tsunewaki, K., and T. Hori, 1967 Distribution of necrosis genes in wheat. IV. Common wheat from Australia, Tibet and Northern Europe. Japan. J. Genetics 42: 245-250.

Tsunewaki, K., and H. Kihara, 1962 Comparative gene analysis of common wheat and its ancestral species. I. Necrosis. Japan. J. Genetics 37: 474-484.

Yamashita, K., and M. Tanaka, 1960 Some aspects regarding the collected materials of Triticum and Aegilops from the Eastern Mediterranean countries. I. Wheat Information Service 11: 24-31. 